\title{
Hubungan pes planus dan keseimbangan statis pada anak sekolah dasar
}

\author{
Zharah Yasmasitha $^{1}$, Nuryani Sidarta ${ }^{2}$
}

\begin{abstract}
ABSTRAK
\section{LATAR BELAKANG}

Keseimbangan merupakan kemampuan tubuh untuk mempertahankan pusat massa tubuh terhadap axis tubuh untuk melawan gravitasi bumi yang dipengaruhi oleh proses sensorik atau sistem saraf, motorik atau muskuloskeletal. Salah satu faktor yang dapat menyebabkan gangguan keseimbangan pada anak yaitu, gangguan muskuloskeletal berupa kelainan bentuk telapak kaki. Hasil penelitian yang sudah ada masih menunjukkan kontroversi sehubungan dengan hal tersebut. Penelitian ini dibuat untuk melihat lebih lanjut hubungan pes planus (kaki datar) dengan keseimbangan statis terutama pada anak sekolah dasar.

\section{METODE}

Penelitian menggunakan metode studi observasional dengan desain cross-sectional yang mengikutsertakan 145 siswa-siswa SD X di Tangerang dan SD Y di Batam. Data dikumpulkan dengan cara wawancara menggunakan kuesioner. Keseimbangan statis diukur dengan metode Standing Stork Test, sedangkan diagnosa pes planus didapatkan dengan metode Wet Foot Print untuk mendapatkan batas lengkung arkus longitudinal medial kaki. Analisis data dilakukan dengan uji Chi-square dengan tingkat kemaknaan yang digunakan 0.05 .
\end{abstract}

\section{HASIL}

Dari 145 responden, didapatkan 18 anak (12.4\%) memiliki keseimbangan statis yang buruk dan 42 anak (29\%) didiagnosa dengan pes planus. Terdapat 18 anak dengan keseimbangan statis yang buruk dengan $16(88.9 \%)$ diantaranya memiliki pes planus. Hasil analisis bivariat menunjukkan terdapat hubungan yang signifikan antara keseimbangan statis dengan pes planus pada anak sekolah dasar $(\mathrm{p}=0.000)$.

\section{KESIMPULAN}

Terdapat hubungan signifikan antara pes planus dan keseimbangan statis.

Kata kunci: keseimbangan statis, pes planus, siswa, sekolah dasar, kaki datar

\author{
${ }^{1}$ Program Studi Kedokteran, \\ Fakultas Kedokteran Universitas \\ Trisakti, Jakarta, Indonesia \\ 2 Departemen Anatomi, Fakultas \\ Kedokteran Universitas Trisakti, \\ Jakarta, Indonesia

\section{Korespondensi:} \\ Nuryani Sidarta \\ Departemen Anatomi, Fakultas \\ Kedokteran Universitas Trisakti, \\ Jakarta, Indonesia \\ Jalan Kyai Tapa Kampus B Grogol, \\ 11440 \\ Email: \\ nuryani_sidarta@trisakti.ac.id
}

J Biomedika Kesehat 2020;3(2):84-89 DOI: 10.18051/JBiomedKes.2020. v3.84-89

pISSN: 2621-539X / eISSN: 2621-5470

Artikel akses terbuka (open access) ini didistribusikan di bawah lisensi Creative Commons Attribution 4.0 International (CC-BY 4.0) 


\section{ABSTRACT}

\section{Relationship between pes planus and static balance in elementary school children}

\section{BACKGROUND}

Balance is the ability to maintain the body in the center of body mass against the fulcrum to fight gravity affected by sensory processes or the nervous, motor or musculoskeletal systems. One of the factors that can cause balance disorders in children is musculoskeletal disorders in the form of deformity of the soles of the feet. The results of existing studies still show controversy regarding this matter. This study was made to further see the relationship between pes planus (flat foot) and static balance especially in elementary school children.

\section{METHODS}

Balance is the ability to maintain the body in the center of body mass against the fulcrum to fight gravity affected by sensory processes or the nervous, motor or musculoskeletal systems. One of the factors that can cause balance disorders in children is musculoskeletal disorders in the form of deformity of the soles of the feet. The results of existing studies still show controversy regarding this matter. This study was made to further see the relationship between pes planus (flat foot) and static balance especially in elementary school children.

\section{RESULTS}

From 145 subject in this study, we found $29 \%$ of the respondent who has pes planus and $12.4 \%$ of it has poor balance static. There is significance relationship between balance static and pes planus in elementary school students from bivariat analysis $(\mathrm{p}=0.000)$.

\section{CONCLUSION}

There is significant relationship between pes planus and static balance.

Keywords: static balance, pes planus, student, elementary school, flat foot

\section{PENDAHULUAN}

Keseimbangan merupakan kemampuan memelihara tubuh dalam pusat massa tubuh terhadap bidang tumpu untuk melawan gravitasi yang dipengaruhi oleh proses sensorik atau sistem saraf, motorik, atau muskuloskeletal. ${ }^{(1)}$ Salah satu faktor yang dapat menyebabkan gangguan keseimbangan pada anak yaitu, gangguan muskuloskeletal berupa kelainan bentuk telapak kaki.

Terdapat tiga jenis bentuk telapak kaki manusia yaitu, normal foot, flat foot, dan cavus foot sesuai struktur arcus pedis atau lengkungan pada telapak kaki manusia. Salah satu bentuk telapak kaki flat foot atau kaki datar dikenal juga dengan sebutan pes planus. Pada penelitian sebelumnya di Indonesia didapatkan bahwa dari 58 anak berusia 8-12 tahun dalam masa usia awal sekolah terdapat 28-35\% anak mengalami deformitas pes planus. Normalnya arkus terbentuk dengan rentang usia 2-6 tahun, karena pada neonatus dan balita terdapat bantalan lemak dibagian bawah kaki bagian tengah (mindfoot) - bantalan lemak ini akan menghilang seiring bertambahnya usia. ${ }^{(2)}$

Keseimbangan adalah kemampuan mempertahankan sikap tubuh yang tepat dan benar pada saat melakukan suatu gerakan. Keseimbangan merupakan kemampuan penting yang digunakan sehari-hari seperti berjalan dan berdiri, melompat, dan bersepeda. Keseimbangan dapat meningkatkan kualitas hidup anak dan bentuk kaki memberikan pengaruh pada kesimbangan berdiri. ${ }^{(2)}$

Menurut penelitian sebelumnya ditemukan bahwa pes planus menyebabkan keseimbangan seseorang menjadi buruk. ${ }^{(3)}$ Namun menurut penelitian lainnya, anak berusia 8-12 tahun di Indonesia tidak ada hubungan pes planus dengan keseimbangan statis karena keseimbangan seseorang lebih ditentukan oleh fungsi neurologis. (2) Sebuah penelitian lainnya menemukan bahwa tidak terdapat perbedaan yang signifikan mengenai keseimbangan statis dalam perbandingan antara berbagai variasi arkus plantar, dengan kata lain keseimbangan seseorang tidak dipengaruhi oleh arkus plantar. ${ }^{(4)}$

Terdapat penelitian yang menyatakan bahwa sekitar $20-30 \%$ dari seluruh anak di dunia mengalami kaki datar (pes planus). ${ }^{(5)}$ Sebuah studi baru menunjukkan bahwa terdapat prevalensi $67 \%$ anak yang mengalami keseimbangan statis disebabkan karena berkurangnya aktivitas anak. ${ }^{6}$

Hasil penelitian yang masih pro dan kontra dari permasalahan tentang pes planus dan dampaknya yang mempengaruhi keseimbangan statis pada anak-anak membuat peneliti tertarik meneliti adanya hubungan pes planus dengan keseimbangan statis pada anak. 


\section{METODE}

Tujuan dilakukannya penelitian ini adalah untuk mengetahui seberapa besar hubungan keseimbangan statis dengan pes planus pada anak sekolah dasar. Penelitian ini dilakukan dengan menggunakan metode observasional analitik dengan pendekatan potong lintang (crosssectional), yaitu dengan melakukan pengukuran atau pengamatan terhadap kedua variabel pada saat yang bersamaan dalam satu waktu.

Penelitian ini dilakukan di wilayah Kabupaten Tangerang di Sekolah Dasar X dan di Sekolah Dasar Y Batam, di mana pada lokasi ini belum pernah dilakukan penelitian mengenai hubungan pes planus dan keseimbangan statis. Pengambilan data dilakukan pada bulan Januari hingga Mei tahun 2019. Populasi dari penelitian ini adalah siswa-siswi SD kelas 1-5 SD di Sekolah Dasar X Tangerang dan SD Y Batam. Sampel yang diteliti adalah yang memenuhi kriteria inklusi dan eksklusi. Kriteria inklusi penelitian ini adalah sehat, usia 7-11 tahun, dan bersedia untuk ikut serta dalam penelitian. Sedangkan kriteria eksklusi pada penelitian ini adalah gangguan sensoris, gangguan struktur tulang, kelemahan otot, memakai alat bantu jalan, obesitas, kelainan bawaan. Teknik pengambilan sampel dalam penelitian ini adalah simple random sampling. Pada simple random sampling, di mana kita menghitung terlebih dahulu jumlah subjek dalam populasi (terjangkau) yang akan dipilih subjeknya sebagai sampel penelitian. Setiap subjek diberi nomor dan dipilih sebagian dari mereka dengan bantuan tabel angka random.

Bahan dan instrumen yang digunakan adalah Standing Stork Test di mana responden diminta untuk berdiri dengan satu ekstremitas dan menempatkan kaki lainnya di lutut dari ekstremitas yang menyangga tubuh. Dilakukan pencatat waktu lamanya responden mampu berdiri tanpa terjadi perubahan posisi tubuh. Responden dinilai memiliki kemampuan keseimbangan statis baik bila dapat mencapai waktu berdiri $>15$ detik untuk laki-laki dan $>10$ detik untuk perempuan. ${ }^{(3)}$

Pemeriksaan tinggi rendahnya arkus atau lengkung kaki longitudinal dapat dilakukan melalui sidik tapak kaki (footprint) dengan memperhatikan batas medial kaki. Alat yang digunakan adalah bantalan tinta dan kertas HVS. Para siswa diminta untuk berdiri tegak di atas bantalan tinta dan dipastikan setiap bagian kaki sudah menginjak bantalan tersebut. Siswa kemudian diminta untuk menginjakkan kedua kaki mereka di atas kertas HVS yang telah ditempel di lantai. Hasil cetakan kemudian diberi nama dan dikeringkan. Seorang siswa dikategorikan memiliki pes planus apabila batas medial plantar pedis tidak melewati garis vertikal yang ditarik dari pertengahan jari kedua ke pertengahan dari tulang calcaneus.

Setiap siswa yang telah dipilih dan memenuhi kriteria inklusi dan setuju untuk mengikuti penilaian diminta menandatangani informed consent, setelah itu dilakukan pengumpulan data, lalu dilanjutkan tes uji Standing Stork Test untuk mengetahui keseimbangan statis yang baik dan tes plantar foot print untuk mengetahui pes planus, data yang sudah didapati dikelompokkan dan dianalisis.

Analisis data yang digunakan dalam penelitian ini adalah analisis univariat dan analisis bivariat. Analisis univariat digunakan untuk melihat penyajian distribusi frekuensi dari seluruh data yang diteliti. Data yang diolah kemudian disajikan dalam bentuk tabel distribusi frekuensi berdasarkan masing-masing variabel untuk presentase. Analisis bivariat digunakan untuk melihat ada tidaknya hubungan antara variabel bebas dan variabel tergantung. Analisis data menggunakan uji Chi-square untuk melihat hubungan antara keseimbangan statis dengan pes planus dengan nilai $\mathrm{p}<0.05$ (derajat kepercayaan $95 \%)$.

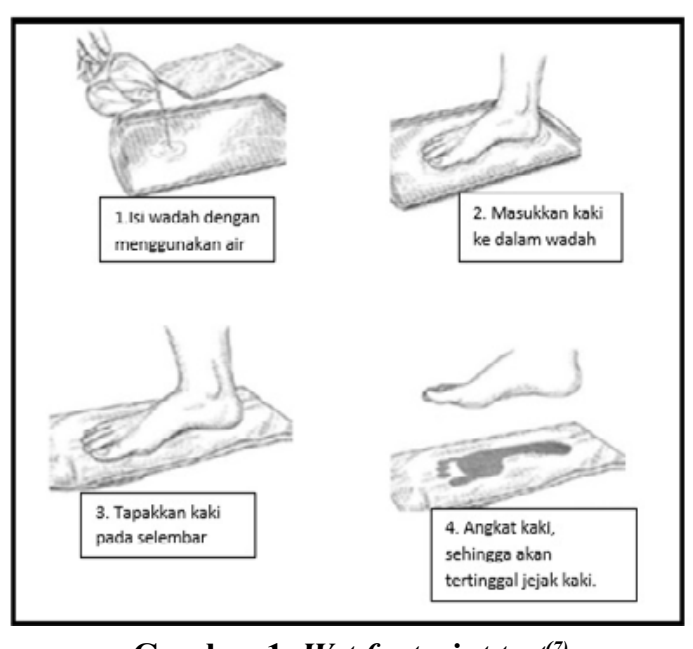

Gambar 1. Wet footprint test $t^{(7)}$

\section{HASIL}

Didapatkan jumlah sampel penelitian sebanyak 145 siswa-siswi yang terdiri dari 72 
siswa-siswi dari SD X, Kabupaten Tangerang dan 73 siswa-siswi dari SD Y, Batam.

Tabel 1. Karakteristik responden

\begin{tabular}{lc}
\hline Karakteristik & n (\%) \\
\hline Jenis kelamin & \\
Laki-laki & $73(50.3)$ \\
Perempuan & $72(49.7)$ \\
Keseimbangan statis & \\
Baik & $127(87.6)$ \\
Buruk & $18(12.4)$ \\
Pes planus & \\
Ya & $42(29.0)$ \\
Tidak & $103(71.0)$ \\
\hline
\end{tabular}

Berdasarkan Tabel 1, diketahui bahwa dari 145 responden, jenis kelamin laki-laki dan perempuan hampir seimbang. Keseimbangan statis baik sebanyak $87.6 \%$ dan dengan arkus kaki normal sebanyak $71.0 \%$. Persentase siswa yang memiliki pes planus adalah $29.0 \%$ yang mengindikasikan bahwa dari 10 siswa didapatkan kira-kira 3 siswa yang memiliki pes planus.

Berdasarkan Tabel 2 dapat dilihat bahwa dari 18 subjek yang memiliki keseimbangan statis buruk sebanyak 16 (88.9\%) memiliki pes planus dan hanya $2(11.1 \%)$ subjek yang dengan arkus kaki normal. Hasil yang sebaliknya didapatkan pada kelompok siswa dengan keseimbangan statis yang baik maka $79.5 \%$ diantaranya memiliki lengkung kaki yang normal. Pada uji Chi-square hubungan pes planus dengan keseimbangan statis didapatkan nilai $\mathrm{p}=0.000$ atau $\mathrm{p}<0.05$ yang artinya terdapat hubungan antara keseimbangan statis dengan pes planus.

\section{PEMBAHASAN}

Padapenelitianinididapatkankarakteristik subjek dari 2 Sekolah Dasar dengan total 145 siswa. Didapatkan distribusi jenis kelamin yang hampir seimbang antara responden laki-laki sebanyak 73 orang dan perempuan 72 orang. Dari total 145 responden didapatkan sebanyak 18 responden $(12.4 \%)$ yang memiliki kemampuan keseimbangan yang buruk dan 16 responden (88.9\%) diantaranya memiliki kondisi pes planus. Hasil ini tidak jauh berbeda dengan hasil penelitian sebelumnya yang mendapatkan data bahwa pada kelompok yang memiliki keseimbangan buruk maka $77.0 \%$ diantaranya memiliki pes planus dan pada uji hipotesis didapatkan ada perbedaan yang signifikan dengan nilai $\mathrm{p}=0.000$. Penjelasan biomekanika yang mendasari kondisi tersebut di atas adalah pada anak-anak yang memiliki pes planus maka terjadi perubahan pada posisi dari tulang talus dan perubahan ini menyebabkan ketidakseimbangan padadistribusi berat tubuh yang pada akhirnya akan memberikan dampak pada kemampuan tubuh untuk mempertahankan keseimbangan. $^{(3)}$

Berdasarkan penelitian lainnya didapatkan prevalensi gangguan keseimbangan statis lebih tinggi pada kelompok siswa yang memiliki pes planus, namun hubungan tersebut didapatkan tidak bermakna. Penjelasan mengenai kondisi ini berdasarkan studi dari Lendra yang menjelaskan bahwa terdapat banyak faktor yang mempengaruhi keseimbangan statis seorang anak selain daripada pes planus dan hal tersebut tidak dilihat secara detail pada penelitian tersebut. ${ }^{(2)}$

Pes planus merupakan kondisi ketika sebagian atau seluruh telapak kaki kontak dengan tanah. Meskipun sebagian besar kejadian pes planus terjadi dalam bentuk fisiologis, akan tetapi jika kondisi tersebut berlanjut menuju tahap yang lebih buruk, maka dapat menimbulkan gejala dan berpengaruh pada fungsi kaki penderitanya. ${ }^{(7)}$ Estimasi prevalensi pes planus berkisar antara 0.6$77.9 \%$ yang terjadi akibat perbedaan kelompok umur, metode yang digunakan, dan sampel yang diikutsertakan dalam penelitian. ${ }^{(8,9)}$ Dalam penelitian ini sendiri didapatkan prevalensi pes

Tabel 2. Hubungan pes planus dengan keseimbangan statis

\begin{tabular}{lcccc}
\hline & \multicolumn{3}{c}{ Bentuk } & \multirow{2}{*}{ Nilai p } \\
\cline { 2 - 4 } Variabel keseimbangan statis & Normal & Pes planus & Total & \\
\cline { 2 - 4 } & $\mathbf{n ~ ( \% )}$ & $\mathbf{n}(\mathbf{\%})$ & $\mathbf{n}(\%)$ & 0.000 \\
\hline Baik & $101(79.5)$ & $26(20.5)$ & $127(100)$ & \\
Buruk & $2(11.1)$ & $16(88.9)$ & $18(100)$ & \\
\hline
\end{tabular}


planus sebesar $29.0 \%$ di mana diantara 145 orang responden, yang mengalami pes planus adalah sebanyak 42 subjek.

Berdasarkan hasil analisis yang telah dilakukan, dapat diketahui bahwa responden dengan kemampuan keseimbangan statis yang buruk memiliki prevalensi pes planus yang lebih tinggi dibandingkan dengan kelompok responden dengan keseimbangan yang baik. Hasil uji bivariat didapatkan adanya hubungan yang signifikan antara keseimbangan statis dengan pes planus $(\mathrm{p}=0.000)$. Hasil yang didapatkan dalam penelitian ini sesuai dengan penelitian sebelumnya yang menemukan adanya hubungan antara keseimbangan statis dengan variasi arkus plantar dan salah satu faktor yang dapat menyebabkan gangguan keseimbangan pada anak yaitu gangguan muskuloskeletal berupa kelainan bentuk telapak kaki. ${ }^{(1,2)}$

Kondisi pes planus pada anak umur lebih muda terjadi karena umur diprediksi sebagai faktor utama yang mempengaruhi terjadinya pes planus, dan kondisi pes planus akan berkurang seiring dengan pertambahan umur anak. ${ }^{(10)}$ Berkurangnya kondisi pes planus pada anak dapat terjadi karena sebagian besar anak mengalami perkembangan lengkung longitudinal kaki pada umur tiga sampai lima tahun. ${ }^{(11)} \mathrm{Hal}$ ini terjadi akibat berkurangnya bantalan lemak pada lengkung medial kaki dan terjadi penyesuaian pertumbuhan lengkung kaki secara menetap. ${ }^{(12)}$ Penelitian lainnya menyatakan bahwa terdapat perbedaan signifikan tumpuan antara anak normal dan anak pes planus. ${ }^{(13)}$ Anak yang memiliki arkus kaki normal dikatakan lebih stabil karena tekanan dari berat badan dibagi secara merata keseluruh telapak kaki. ${ }^{(14)}$ Kondisi yang berbeda ditemukan pada anak dengan pes planus di mana sebagain besar tumpuan berat badan jatuh pada area jari ke-2 dan ke-3. Adanya kondisi overweight dapat berhubungan dengan bertambahnya tekanan pada lengkung kaki yang terjadi secara terus-menerus saat seseorang berjalan. ${ }^{(15)}$

Kondisi kaki dengan arkus kaki normal mempunyai rentang waktu lebih lama dalam mempertahankan keseimbangan bila dibandingkan dengan anak yang memiliki ganggun pada arkus kaki. Pada anak dengan pes planus maka terjadi perubahan pada postur tubuh. Perubahan ini akan mengakibatkan perubahan titik pusat gravitasi yang kemudian akan mempengaruhi keseimbangan tubuh. ${ }^{(16)}$

Kondisi pes planus juga berarti bahwa kaki kehilangan lengkung kaki yang memiliki fungsi sebagai komponen pengungkit tubuh. Adanya gangguan fungsi ini akan menyebabkan ekstremitas bawah tubuh memerlukan gaya yang besar saat berjalan maupun berlari. Kondisi ini akan membuat anak cepat merasa lelah saat berjalan maupun berlari. Selain itu, keseimbangan juga merupakan kemampuan penting yang digunakan sehari-hari seperti berjalan, berdiri, berlari, melompat, dan bersepeda. ${ }^{(17)}$

Selain penemuan di atas, pada kelompok anak yang memiliki keseimbangan buruk, terdapat 2 anak (11.0\%) yang memiliki lengkung kaki yang normal. Hal ini dapat disebabkan bahwa terdapat faktor-faktor lain yang juga dapat mempengaruhi kemampuan keseimbangan statis seorang anak. Salah satunya adalah tinggi badan. Berdasarkan penelitian yang dilakukan tahun 2009, dikatakan bahwa semakin rendah letak titik berat terhadap bidang tumpuan akan semakin stabil posisi tubuh. ${ }^{(18)}$ Selain faktor tinggi badan maka fungsi keseimbangan tubuh melibatkan diantaranya aktivitas kekuatan otot dan akumulasi jaringan adipose. Otot yang kuat merupakan otot yang dapat berkontraksi dan rileksasi dengan baik, jika otot kuat maka keseimbangan dan aktivitas sehari-hari dapat berjalan dengan baik. Massa otot yang rendah juga dapat menyebabkan kegagalan biomekanik dari respon otot dan hilangnya mekanisme keseimbangan tubuh. ${ }^{(19)}$ Peningkatan indeks massa tubuh akan mempengaruhi kekuatan otot, sehingga jika otot tersebut lemah dan massa tubuh bertambah maka akan terjadi masalah keseimbangan tubuh saat berdiri maupun berjalan. (20) Penelitian ini tidak melihat pengaruh faktorfaktor tersebut yang dinilai dapat menjadi faktor perancu yang mempengaruhi keseimbangan seorang anak selain pes planus.

\section{KESIMPULAN}

Terdapat hubungan yang signifikan antara keseimbangan statis dengan pes planus $(\mathrm{p}=0.000)$. Mengingat pentingnya kemampuan keseimbangan statis seorang anak dalam melakukan aktifitas sehari-hari maka saran peneliti untuk penelitian berikutnya adalah menilai faktor-faktor lain yang juga dapat mempengaruhi keseimbangan statis seorang anak. Peneliti juga menyarankan untuk 
melakukan penelitian pada usia yang lebih dini sehingga tindakan preventif dapat dilakukan lebih dini.

\section{UCAPAN TERIMA KASIH}

Sekolah Dasar Cihuni 2 Tangerang dan Sekolah Dasar Kartini 1 Batam.

\section{KONFLIK KEPENTINGAN}

Semua penulis menyatakan tidak ada konflik kepentingan dalam penelitian ini.

\section{REFERENSI}

1. Boccolini G, Brazzit A, Bonfanti L, Alberti G. Using balance training to improve the performance of youth basketball players. Sport Sci Health. 2013 Aug;9(2):37-42. doi: 10.1007/s11332-013-0143-z

2. Lendra, MD, Santoso TB. Beda pengaruh kondisi kaki datar dan kaki dengan arkus normal terhadap keseimbangan statis pada anak usia 8-12 tahun di Kelurahan Karangasem, Surakarta [Internet]. Jurnal Ilmiah Fisioterapi. 2009;9(2):49-58. Available from: https://ejurnal.esaunggul.ac.id/ index.php/Fisio/article/view/625

3. Syafi'i M, Pudjiastuti SS, Prihantiko P. Beda Pengaruh Arkus Kaki Terhadap Keseimbangan Statis Anak Usia 9-12 Tahun Di SD Negri Mojolegi, Teras, Boyolali. Jurnal Kesehatan. 2016;3(3):3514. doi: $10.26630 / \mathrm{jk} . v 7 \mathrm{i} 3.215$

4. Alonso AC, Peterson M, Duganieri M, et al. The Effect of Foot Morphology and Anthropometry On Unipodal Postural Control. Motriz: Rev Educ Fis. 2016;1(22). doi: 10.1590/S198065742016000100013

5. Evans AM, Rome K. A Cochrane review of the evidence for non-surgical interventions for flexible pediatric flat feet. Eur J Phys Rehabil Med. 2011;47(1):69-89. PMID: 21448121.

6. Wardanie S, Herawati I, Wahyuni. Prevalensi Kelainan bentuk kaki (pes planus) pada anak usia 6-12 tahun di kota Surakarta [skripsi]. Surakarta: Universitas Muhammadiyah Surakarta; 2013.

7. Haendlmayer KT, Harris NJ. (ii) Flatfoot deformity: an overview. Orthop Trauma. 2009;23(6):395403. doi: 10.1016/j.mporth.2009.09.006

8. Evans AM. Screening for foot problems in children $:$ is this practice justifiable?. J Foot Ankle Res. 2012;5(18):1-10. doi: 10.1186/1757-1146-5-18.

9. Ariani L, Wibawa A, Muliarta I. Aplikasi Heels Raises Exercise dapat meningkatkan lengkungan kaki dan keseimbangan statis pada anak-anak flat foot usia 4-5 tahun di TK Aisyiyah Bustanul Athfal 3 Denpasar [Internet]. Majalah Ilmiah Fisioterapi Indonesia. 2015:3(3):1-11. Available from: https:// ojs.unud.ac.id/index.php/mifi/article/view/13128

10. Ali M, Asadullah M, Amjad I. Prevalence of the flat foot in 6-10 years old school going children [Internet]. Rawal Medical Journal. 2013;38(4):68. Available from: https://www.bibliomed. org $/ ? \mathrm{mno}=38128$

11. Atik A, Ozyurek S. Flexible flatfoot. North Clin Istanb. 2014;1(1):57-64. Published 2014 Aug 3. doi:10.14744/nci.2014.29292

12. Vergara-Amador E, Serrano Sánchez RF, Correa Posada JR, et al. Prevalence of flatfoot in school between 3 and 10 years. Study of two different populations geographically and socially. Colomb Med (Cali). 2012 Jun 30;43(2):141-6. PMID: 24893055; PMCID: PMC4001940.

13. Kim MK, Lee YS. Kinematic analysis of the lower extremities of subjects with flat feet at different gait speeds. J Phys Ther Sci. 2013;25(5):531-533. doi:10.1589/jpts.25.531

14. Dabholkar A, Shah A, Yardi S. Comparison of Dynamic Balance Between Flat Feet and Normal Individuals Using Star Excursion Balance Test [Internet]. Indian Journal of Physiotherapy and Occupational Therapy-An International Journal. 20122;6(3): 27-31. Available from: https://api. semanticscholar.org/CorpusID:124661058

15. Ezema CI, Abaraogu UO, Okafor GO. Flat foot and associated factors among primary school children: A cross-sectional study. Hong Kong Physiother J. 2014;32(1):13-20. doi: 10.1016/j. hkpj.2013.05.001

16. Nugroho AS, Nurulita FF. Hubungan antara Pes Planus Dengan Keseimbangan Dinamis pada Murid MI Nurul Karim Colomadu. Jurnal Keterapian Fisik. 2019;4(1):6-14. doi: 10.37341/ jkf.v4i1.120

17. Atamturk D. Relationship of flatfoot and high arch with main anthropometric variables. Acta Orthop Traumatol Turc. 2009;43(3):254-259. doi:10.3944/ AOTT.2009.254

18. Chang YW, Wu HW, Hung W, et al. Postural Responses in Various Bases of Support and Visual Condition in the Subjects with Functional Ankle Instability [Internet]. International Journal of Support and Exercise Science. 2009;1(4):87-92. Available from: https://api.semanticscholar.org/ CorpusID:53555466

19. Kurnia, NLPG, Wibawa A, Adiputra LMSIH. Hubungan Indeks Massa Tubuh (IMT) dengan Keseimbangan Statis Pada Mahasiswa Fakultas Kedokteran Universitas Udayana. Majalah Ilmiah Fisioterapi Indonesia [Internet]. 2016;4(2):29-33. Available from: https://ojs.unud.ac.id/index.php/ $\mathrm{mifi} /$ article/view/22074

20. Mei Z, Grummer-Strawn LM, Pietrobelli A, Goulding A, Goran MI, Dietz WH. Validity of body mass index compared with other bodycomposition screening indexes for the assessment of body fatness in children and adolescents. Am J Clin Nutr. 2002;75(6):978-985. doi:10.1093/ ajen/75.6.978 